\title{
Do demand and profitability stimulate capital accumulation? An analysis for Brazil
}

\author{
Henrique Morrone
}

ABSTRACT

This article tests whether the profit share of GDP and capacity utilization affect capital accumulation in Brazil in the period 1950-2008 (in the sense of Granger causality). The methodology developed by Toda and Yamamoto (1995) is used to verify the Granger non-causality hypothesis. The results show that capacity utilization "Granger-causes" capital accumulation in the Brazilian economy and, also that the profit share of GDP does not "Granger-cause" the national investment-capital ratio. This corroborates the Kaleckian proposal based on the fundamental role of the accelerator, and suggests that the Brazilian economy can grow with either a concentration or a de-concentration of income, provided a suitable institutional arrangement is in place. 


\section{I}

\section{Introduction}

Weak economic performance is a problem that affects many countries. A low level of economic activity can lead the economy into a vicious cycle of modest productivity. The reduction of effective demand is one of the factors explaining the mediocre economic performance of a group of countries. By contrast, robust demand growth can stimulate production in dynamic sectors and foster economies of scale, productivity growth, and economic expansion.

In that connection, redistributing income towards workers can fuel demand and economic activity in countries with large domestic markets. Redistribution can expand the domestic market and thus encourage considerable economies of scale. Moreover, if the redistribution of income towards the workers produces education and health improvements, these will also have positive effects on labour productivity and long-term economic growth. In some countries, this can even reduce political instability, thereby facilitating institutional reforms and promoting the supply of public goods.

For those reasons, it is crucial to analyse the growth regime of the Brazilian economy to determine whether redistributing income in favour of workers causes the economy's output to expand. If the growth regime is wage-led, redistributing income will produce positive effects. By contrast, if the demand regime is profit-led, redistribution will cause economic activity to contract.

The key objective of this paper is to verify whether the profit share of GDP and capacity utilization Grangercaused capital accumulation in the Brazilian economy in the period 1950-2008. In other words, the aim is to test whether variations in the profits-GDP ratio and capacity utilization precede variations in capital accumulation. Based on the ideas of Kalecki (1971) and Steindl (1952), the article will analyse the validity of the investment function for the case of Brazil and, consequently, will identify the economy's growth regime (wage-led or profit-led). For the period under analysis, a data sample taken from IPEA (2011) and Marquetti (2000) spanning 1950 to 2008 was used. The latter author's database on national capital was used, extended to 2008; and the technique developed by Toda and Yamamoto (1995) was used to test causality between the time series for the variables capital accumulation, profits-GDP ratio, and capacity utilization.

This article has five sections following this Introduction. Section II briefly reviews the recent performance of the Brazilian economy; section III considers the relation between distribution and economic activity; section IV describes the methodology used and section $\mathrm{V}$ presents the results. Lastly, section VI concludes.

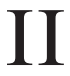

\section{The Brazilian economy in the 2000 decade:}

\section{a brief review}

The Brazilian economy has grown vigorously since the middle of the 2000 decade. Between 2004 and 2010, gross domestic product (GDP) expanded at a rate of $4 \%$ per year, and per capita GDP rose by $2.8 \%$ per year, even after the effects of the international financial crisis that reached Brazil as from the fourth quarter of 2008. That performance almost doubled the growth recorded between 1980 and 2003, when the economy expanded at an average annual rate of $2.2 \%$. It should be noted that
Brazil, which was included in the high-growth country group during the golden age of capitalist development (1950-1973), when GDP expanded by 7\% per year, formed part of the low-growth group during the neoliberal capitalism period (1980-2007). Nonetheless, despite recovering a degree of dynamism, the country grew more slowly than in 1950-1973, and also more slowly than the developing economies generally between 2004 and 2010 (United Nations, 2010). 
A brief summary of the reasons for the recovery offers insight into the changes in the conduct of economic policy compared to the previous period and provides important elements for the analyses performed in this article.

The international panorama prevailing up to 2008 contributed to the results achieved in Brazil. The global economy grew rapidly, driven by China and India. In the first few years of the decade of 2000, the Brazilian economy benefited from export growth and highly favourable international prices. The country's net external debt at the end of 2007 stood at US\$ 49.3 billion, below that prevailing in 1980 in nominal terms. Brazil became less vulnerable to international crises, and it became a major recipient of net direct investment. When the international crisis hit, Brazil had a large volume of reserves and capacity to apply countercyclical policies.

A key feature of the expansion was the pursuit of a development programme based on the domestic market, with three key measures. The first was the adoption by the Brazilian government of a plan geared towards economic development. The Growth Acceleration Plan (PAC) represented the recovery of the State's role in economic planning and coordination of public investments and of State and private enterprises. As shown in figure 1, the investment rate recovered rapidly after the adoption of the PAC, rising from $15.9 \%$ in 2005 to $19.5 \%$ in 2010 .

The second measure was the implementation of redistributive policies, such as the Bolsa Família family subsidy programme and real increases in the minimum wage, which were instrumental in boosting family consumption and stimulated economic activity. Figure 2 shows the trend of social spending in relation to GDP for 1994-2008. Economic policy changed course in the decade of 2000. One of the consequences of the redistribution was an improvement in the income distribution, with the Gini coefficient, which measures the degree of inequality in the economy, dropping from 0.61 in 1990 to 0.54 in 2009 (IPEA, 2011), thereby indicating a reduction in the inequality of labour incomes.

The third measure was the expansion of credit supply across many segments of the financial market, with the State-owned banks leading the process. Thanks to increased lending from public and private banks, the amount of credit in relation to GDP grew considerably from 2000 to 2010.

One result of the domestic-market-led expansion policy was a fall in the unemployment rate, which dropped from $10.5 \%$ in December 2002 to $5.3 \%$ in December 2010. In addition, the increase in formal employment was fundamental for securing political and economic backing for the set of measures adopted by the Brazilian government.

Reducing inequality and improving living conditions among underprivileged population groups can stimulate growth, for two reasons. Firstly, these developments improve people's nutrition in terms of both quality and quantity, which translates into labour productivity gains.

FIGURE 1

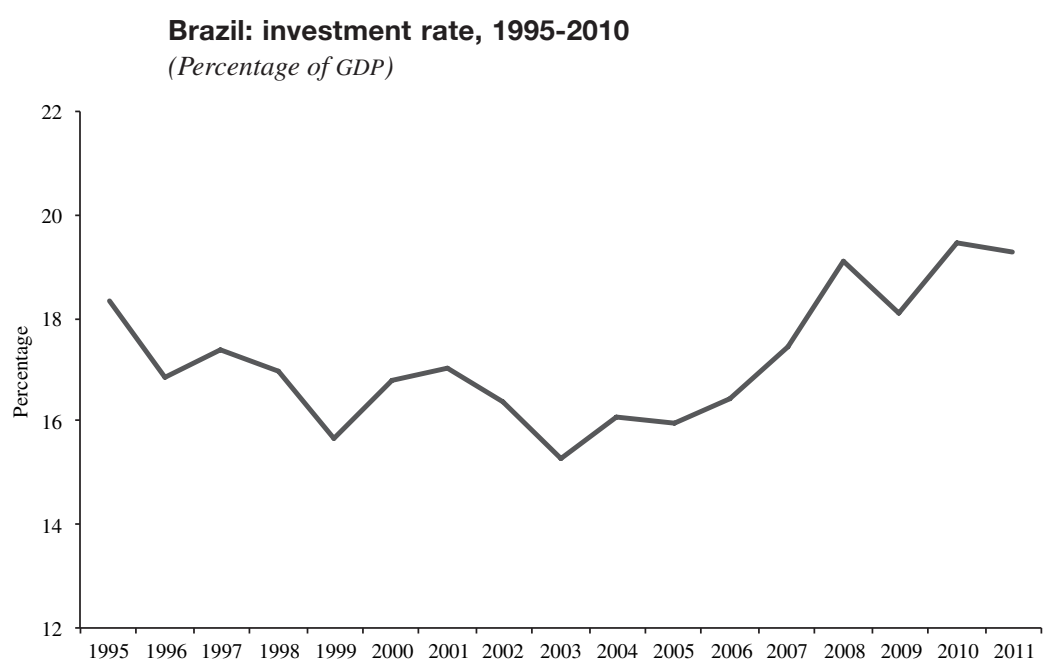

Source: Prepared by the author, on the basis of Brazilian Geographical and Statistical Institute (IBGE), "Tabela de recursos e usos", 2011 [online] http://www.ibge.gov.br/home/estatistica/economia/contasnacionais/2011. 
FIGURE 2

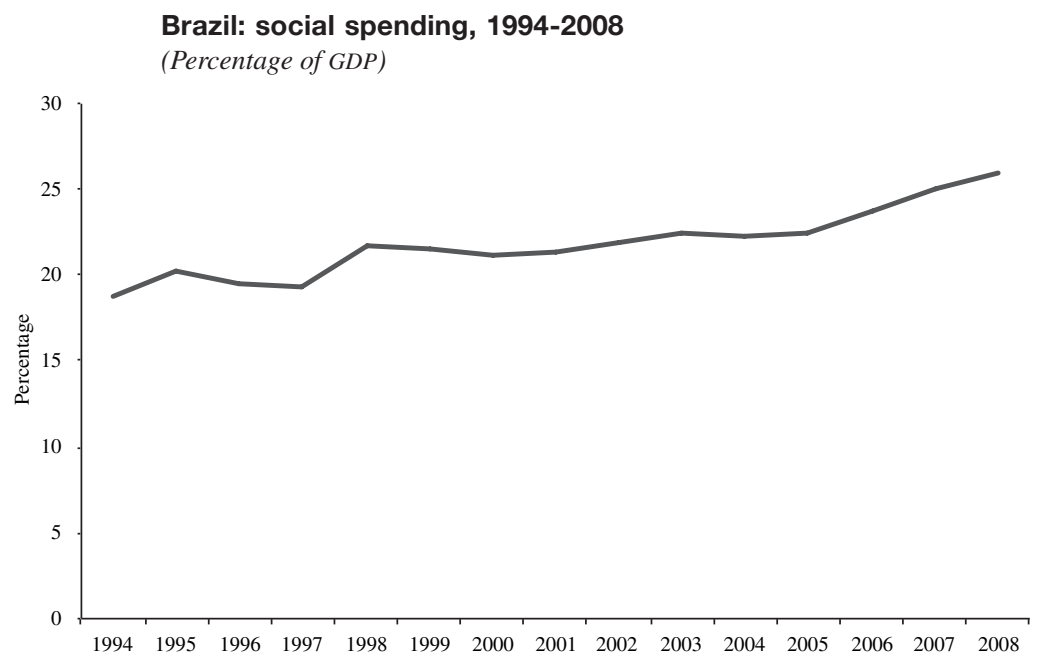

Source: Prepared by the author, on the basis of Brazilian Geographical and Statistical Institute (IBGE), "Tabela de recursos e usos", 2011 [online] http://www.ibge.gov.br/home/estatistica/economia/contasnacionais/2011 and Economic Commission for Latin America and the Caribbean (ECLAC).

Income redistribution reduces poverty, with positive effects on health and education (Deaton, 2003), which in turn increases labour productivity in the medium and long terms. Secondly, in egalitarian economies, it is easier to reach consensus to implement reforms, and this reduces political instability.

Throughout the period under analysis the goal of monetary policy was to control inflation, except at the peak of the international financial crisis between late 2008 and the first half of 2009. High interest rates have repercussions for fiscal policy and the cost of servicing the public debt. A reduction in real and nominal interest rates can make it possible to change the composition of public expenditure, reducing the cost of debt service and enabling increased investment and public spending, while lowering taxes.

Another significant effect is on the exchange rate. The spread between international interest rates and the yield on Brazilian government debt was a major factor in attracting financial resources and, consequently, causing the real to appreciate. An overvalued exchange rate produces perverse effects on economic growth. Firstly, it increases the current account deficit and the need to attract foreign saving through the capital account, which generates additional external liabilities. Secondly, it reduces the competitiveness of industry, thereby speeding up the medium- and long-term deindustrialization process. Nonetheless, exchange-rate appreciation also makes it cheaper for the industrial sector to purchase machinery and equipment, which could generate productivity growth.

In fact, an appreciated exchange rate helps to restrain domestic inflation, which has positive effects on the real wage and, hence, on consumption. This can stimulate growth in large economies that have a broad domestic market. Thus, the net effect on the economy of exchange-rate overvaluation can be either expansionary or contractionary, depending on the specifics of each region.

Table 1 summarizes economic growth in Brazil between 1989 and 2008, which gathered pace after 2003.

TABLE 1

Brazil: rate of growth of gross domestic product (GDP), 1989-2008 (Percentages)

\begin{tabular}{llc}
\hline Period & GDP & Net national capital \\
\hline $1989-2003$ & 2.21 & 2.63 \\
$1989-1997$ & 2.67 & 2.98 \\
$1997-2003$ & 1.60 & 2.16 \\
$2003-2008$ & 4.70 & 3.02 \\
\hline
\end{tabular}

Source: Prepared by the author. 


\section{III}

\section{Income inequality and economic activity}

Economic development is the outcome of profound structural shifts towards activities that generate greater value added and offer dynamic economies of scale. ${ }^{1}$ The interaction between supply and demand, and the distribution of the benefits obtained from the process of expanding the production surplus, play a significant role in explaining development. Accordingly, analysing certain aspects of the relation between the income distribution and the level of economic activity is crucial for gaining a better understanding of the economic growth process.

Analysis of whether redistributing income in favour of workers can induce growth in economic activity has been a constant in economics literature. The empirical and theoretical results are varied, and they highlight the complexity of the relationship between the two variables.

Some studies, including Berni, Marquetti and Kloeckner (2002) and Bagolin, Gabe and Ribeiro (2003), contain tests of the Kuznets curve for the southern region of Brazil. Kuznets (1966) argues that, irrespective of the initial level of inequality, economic growth can lead to equality of incomes in the long term. The author argues that in its initial stages, inequality would be pro-growth. The Kuznets curve, in the form of an inverted "U", establishes strong empirical evidence that in the intermediate stages of development, a deepening of inequality would be a necessary and natural phenomenon. Although in the long run, egalitarian forms would predominate, this would be a natural consequence of the economic growth process. This argument is used to claim that an increase in the relative size of industry should lead to productivity growth, leading in turn to an increase in the pay of specialized workers. The shortage of skilled workers and capital would push up the remuneration of labour in the initial and intermediate stages of development; but, over time, the supply of skilled workers would increase, so their pay would tend to decline, thereby reducing the degree of inequality in the economy.

Nonetheless, studying inequality on a bidimensional basis is problematic; and the theoretical arguments in favour of equality need to be analysed. If income redistribution improves education and health levels, this will generate

\footnotetext{
${ }^{1}$ Dynamic economies of scale are generated through technological progress, gains in learning, external economies, and the division of labour. The process of gains in learning can improve capacity to implement innovations.
}

economic growth because labour productivity is positively correlated with education and health in the long term. If the relation between absolute income and the level of health is concave, redistributing income towards workers will improve the population's health (Deaton, 2003) which, in turn, will help keep it above the poverty line. Consequently, the effects on education and access to health care will stimulate long-term economic growth. In addition, in a wage-led economy, prosperity can be achieved through redistributive policies.

In an economy in which wages have a strong effect on growth, capital accumulation is encouraged by the remunerations paid to labour (and consumption). In that case, the demand effect (measured by the accelerator) would be an essential element explaining accumulation, while the share of profits in GDP would be a less important explanatory variable. For structuralists, the accelerator (demand effect) is the key to explaining accumulation, since its effect on investment is greater than that of profits in most developing countries (Taylor, 1983).

Redistribution towards workers can generate an economic expansion through various channels, including the reduction of political instability and credit constraints. Greater stability can stimulate industrial investment, which leads to productivity growth; whereas an easing of credit constraints can increase productivity through knowledge accumulation. Moreover, a reduction in instability can promote institutional reforms and the supply of public goods, which in turn promotes greater cohesion and facilitates consensus around a common direction and strategy for national development. Income redistribution also expands the domestic market and thereby generates considerable economies of scale. Ros (2000) suggests that equality can reduce incentives for economic agents to engage in rent-seeking activities.

A similar result can be reached through a microeconomic analysis. According to the utility approach, abandoning the hypothesis of exogenous preferences leads to the conclusion that the income distribution can maximize aggregate utility in the economy. This becomes clear when individual utility is treated as a function of the welfare of other individuals in the community (Bortis, 1997).

Accordingly, redistributing income towards workers can raise the aggregate utility level, because the utility gain in low- and middle-income segments compensates 
for the loss of utility among the upper-income brackets. In contrast, a concentration of income would act perversely. At least from the theoretical standpoint, an individual's utility can be increased if other citizens receive a minimum quantity of goods. In that context, redistribution can be justified if preferences are endogenous and are interrelated.

The foregoing arguments show that the relation between inequality and the growth of economic activity is quite complex. Income inequality can stem from different factors, and it is important to discover which of them is the predominant explanation. If the improvement in education and health levels among the population compensates for reduced domestic saving effects, then income redistribution will be crucial for expanding the economy. Consequently, it is important to ascertain the effects of inequality in a broad sense, including inequality in the political domain, inequality of income and unequal access to land. The next section describes the data sources and methodology used in this article.

\section{IV}

\section{Data sources and the Toda and Yamamoto (1995) procedure}

This article performs Granger non-causality tests on the Kaleckian investment function for Brazil in the period 1950-2008. In the original proposals made by Kalecki (1971) and Steindl (1952), the specification of the normalized investment function $(\mathrm{g}=\mathrm{I} / \mathrm{K})$, includes the share of profits in GDP (profit-share) $(\pi)$ and capacity utilization $(u)$ as independent variables. In the case of $\pi$, this is calculated as the quotient between total profits and value-added. Capacity utilization is estimated through the ratio between value added and national capital, according to the neo-Kaleckian literature. The raw data used to calculate investment, national capital and the profit share of GDP were taken from statistics contained in IPEA (2011) and Marquetti (2000). The latter author's database on national capital extended to 2008 was used.

The series are annual, and constant 1995 values are used as the base. The econometric method chosen is the procedure developed by Toda and Yamamoto (1995) to test for Granger non-causality. All estimations were made with the programme.

The Granger non-causality test assumes steadystate variables. The traditional tests are not suitable in the presence of integrated variables, because they do not follow a standard distribution. To overcome that problem, unit root and co-integration tests are applied.

Nonetheless, the unit root econometric tests (the Dickey-Fuller test and the Phillips-Perron test) are ineffective with respect to the alternative hypothesis of steady-state variables, and are not reliable in the case of relatively small samples (Toda and Yamamoto, 1995, p. 226). The Johansen co-integration test suffers from similar shortcomings, because its results are sensitive to the different specifications adopted. This increases uncertainty in the results of the causality test, owing to the presence of biased preliminary tests (Marquetti, Koshiama and Alencastro, 2009, p. 375).

The Toda and Yamamoto (1995) method does not have the shortcomings of the traditional procedures described above. This alternative method can be applied to co-integrated series, non-cointegrated series, or series with different orders of integration, without the need to perform unit root tests. It is also the most appropriate test for relatively small samples (Marquetti, Koshiama and Alencastro, 2009, p. 376; and Yamada and Toda, 1998).

The procedure developed by Toda and Yamamoto (1995) consists of applying a Wald test to verify the constraints on the parameters of an augmented vector autoregressive (VAR) model in levels and estimated by ordinary least squares (OLS). Toda and Yamamoto (1995) showed that the application of the Wald test on the constraints on the parameters of an augmented $\operatorname{VAR}\left(\mathrm{k}+e_{\text {max }}\right)$ with variables in levels, follows an asymptotic chi-squared $\left(\chi^{2}\right)$ distribution, irrespective of whether or not the system is cointegrated. The optimal number of lags is $k$, and $e_{\max }$ is the maximum order of integration of the time series. Thus the Wald test is applied to the first $k$ parameters to verify the validity of the hypothesis of Granger non-causality. The other lagged parameters are not tested, because they only serve to ensure the presence of an asymptotic $\chi^{2}$ distribution.

The procedure developed by Toda and Yamamoto (1995) to test for Granger non-causality has three steps. 
Firstly, the number of lags $(k)$ must be defined along with a maximum order of integration of the system $\left(e_{\max }\right)$. As in the original proposal by Toda and Yamamoto (1995), in this article the optimal number of lags will be chosen using the Schwartz information criterion (SIC). ${ }^{2}$ It was found that the maximum order of integration of the system $\left(e_{\max }\right)$ follows a first-order integrated process, since most of the economic variables are first-order integrated, I(1).

The next step consists of the direct estimation of a $\operatorname{var}\left(\mathrm{k}+e_{\max }\right)$ in levels for the variables analysed. The details of the equations for the first specification are set out below:

$$
\begin{aligned}
& (g)_{a}=c_{1}+\alpha_{1 j} \sum_{j=1}^{k}(g)_{a j}+\delta_{1 j} \sum_{j=1}^{k}(\pi)_{a j}+\beta_{1 j} \sum_{j=1}^{k}(u)_{a j} \\
& +\alpha_{1 l} \sum_{l=k+1}^{e}(g)_{a}+\delta_{1 l} \sum_{l=k+1}^{e}(\pi)_{a}+\beta_{1 l} \sum_{l=k+1}^{k}(u)_{a}+\tau_{1 t} \\
& (\pi)_{a}=c_{2}+\alpha_{2 j} \sum_{j=1}^{k}(g)_{a j}+\delta_{2 j} \sum_{j=1}^{k}(\pi)_{a j}+\beta_{2 j} \sum_{j=1}^{k}(u)_{a j} \\
& +\alpha_{2 l} \sum_{l=k+1}^{e}(g)_{a}+\delta_{2 l} \sum_{l=k+1}^{e}(\pi)_{a}+\beta_{2 l} \sum_{l=k+1}^{k}(u)_{a}+\tau_{2 t}
\end{aligned}
$$

2 Although the Akaike information criterion (AIC) could be used to define a maximum order of integration of the system, its application tends to select less parsimonious models.

$$
\begin{aligned}
& (u)_{a}=c_{3}+\alpha_{3 j} \sum_{j=1}^{k}(g)_{a j}+\delta_{3 j} \sum_{j=1}^{k}(\pi)_{a j}+\beta_{3 j} \sum_{j=1}^{k}(u)_{a j} \\
& +\alpha_{3 l} \sum_{l=k+1}^{e}(g)_{a}+\delta_{3 l} \sum_{l=k+1}^{e}(\pi)_{a}+\beta_{3 l} \sum_{l=k+1}^{k}(u)_{a}+\tau_{3 t}
\end{aligned}
$$

where:

$\mathrm{g}=$ accumulation rate $(\mathrm{I} / \mathrm{K})$;

$\pi=$ profit share of GDP;

$u=$ capacity utilization $(\mathrm{Y} / \mathrm{K})$.

The last stage consists of performing the Wald constraints test on the first $k$ parameters, to examine the hypothesis of Granger non-causality. Thus, the profit share of GDP Granger-causes the capital accumulation rate, if the hypothesis $H_{0}: \delta_{1 j}=0$ is rejected. At the same time, installed capacity $(u)$ Granger-causes accumulation if the hypothesis $H_{0}: \beta_{1 j}=0$ is rejected. In the tests developed to determine whether accumulation Granger-causes both the profit share of GDP and installed capacity, respectively, the procedure was analogous.

The procedure developed by Toda and Yamamoto (1995) to test the hypothesis of Granger non-causality between the variables, is thus a suitable method for identifying the variables that would affect the national rate of capital accumulation, and can provide elements to verify whether the economy is wage-led or profit-led. It should be stressed that the Granger non-causality test, on its own, indicates the time sequence between the variables under study and is predictor of future behaviour of the variables.

\section{Results}

This section considers the main results obtained. Firstly, an analysis is performed of the order of integration of the variables studied. Then, the Toda and Yamamoto (1995) method is used to test the hypothesis of Granger non-causality between the variables.

Figure 3 shows the temporal behaviour of capital accumulation $(g)$, the profit share of GDP $(\pi)$ and capacity utilization $(u)$ in the period spanning 1950 to 2008 . The analysis in this study does not extend beyond 2008, because there are no estimates of national capital after that date; 1995 was taken as the base year for prices, as the series was annual.

The statements made above are confirmed, particularly in relation to the recovery of the capital accumulation and investment rates as from 2003. In addition, the ratio between profits and GDP declines from 2003 on (Marquetti and Porsse, 2014), which highlights the wage growth during the period.

Table 2 shows the results of the unit root tests for the explanatory variables of the neo-Kaleckian accumulation function. The augmented Dickey-Fuller test was applied to verify the order of integration of the series.

An analysis of table 2 shows that the variables profits-GDP ratio $(\pi)$ and capacity utilization $(u)$ may have a unit root. Nonetheless, the results are not conclusive for those two variables, since they are sensitive to the specification adopted. It can also be seen that the "capital accumulation" variable has a unit root. The first 
difference of the variables was tested, which indicated the stationarity of the series.

The Toda and Yamamoto (1995) procedure was applied to the neo-Kaleckian capital accumulation function to establish whether the series display Granger unidirectional or bidirectional causality. In the first stage of the test, the level of the augmented vector autoregressive VAR model must be defined; this means specifying the number of lags $(k)$ and a maximum order of integration of the system $\left(e_{\max }\right)$.
Further analysis of table 2 shows that the maximum order of integration of the system $\left(e_{\max }\right)$ is 1 . The number of lags $(k)$ was obtained from the Schwartz test and proved equal to 2 . Then, a $\operatorname{VAR}(3)$ in levels was estimated to test Granger non-causality, and a $\operatorname{VAR}(4)^{3}$

3 Tests were performed to verify the existence of autocorrelation in the residuals: the LM test and White heteroscedasticity test on the specification of the intensive-form investment function.

Brazil: temporal behaviour of the series on capital accumulation (g), investment rate, profit-GDP ratio $(\pi)$, and capacity utilization $(u), 1950-2008$

Capital accumulation $(g)$

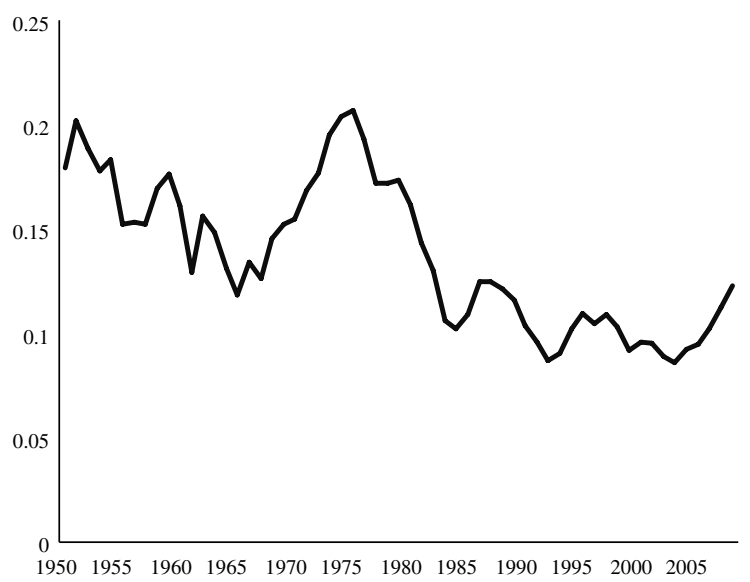

Capacity utilization $(u)$

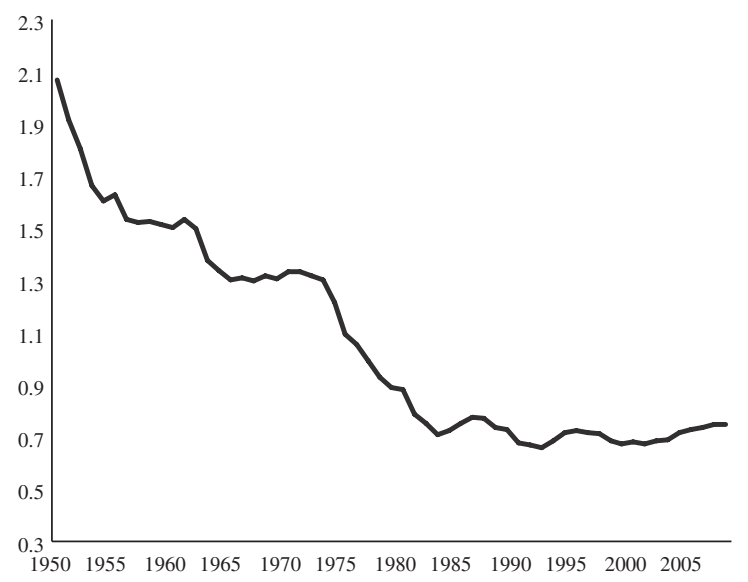

Profit share of GDP $(\pi)$

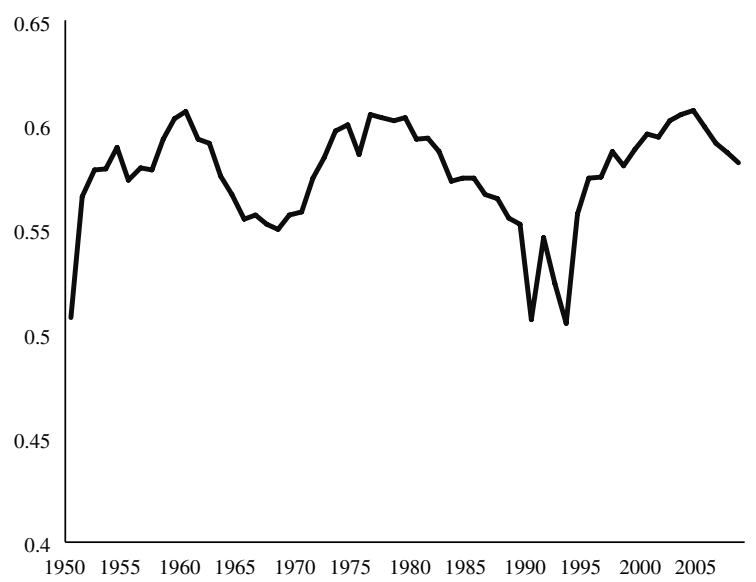

Investment rate

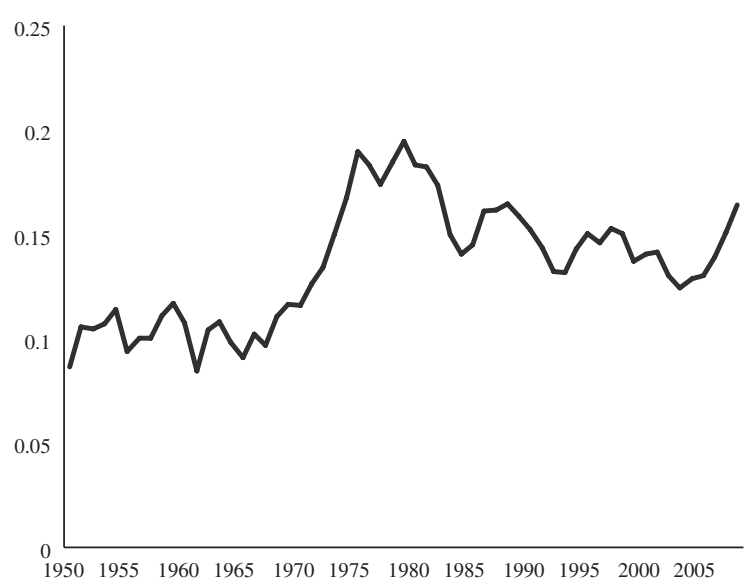

Source: Brazilian Geographical and Statistical Institute (IBGE), “Tabela de recursos e usos”, 2011 [online] http://www.ibge.gov.br/home/ estatistica/economia/contasnacionais/2011; Institute of Applied Economic Research (IPEA), "Estatísticas sociais", Ipeadata, 2011 [online] http://www.ipeadata.gov.br; and A.A. Marquetti, "Estimativa do estoque de riqueza tangível no Brasil, 1950-1998", Nova Economia, vol. 10, No. 2, Minas Gerais, Federal University of Minas Gerais, 2000.

Note: Use was also made of the national capital database of Marquetti (2000) extended to 2008 and Marquetti and Porsse (2014). Capital accumulation was estimated through the ratio between investment and national capital. Capacity utilization was obtained by dividing output by national capital, in accordance with the neo-Kaleckian approach. Lastly, the investment rate is merely the ratio between investment and output. 
TABLE 2

Unit root test for the regression variables

\begin{tabular}{|c|c|c|c|c|}
\hline Variables & Test modality & Number of lags & Augmented Dickey-Fuller test & $p$-value \\
\hline \multirow{3}{*}{ Capital accumulation $(g)$} & Without constant & 1 & -0.95 & 0.30 \\
\hline & With constant & 1 & -1.59 & 0.47 \\
\hline & With constant and trend & 1 & -2.25 & 0.45 \\
\hline \multirow{3}{*}{ Profit-GDP ratio $(\pi)$} & Without constant & 1 & 0.47 & 0.81 \\
\hline & With constant & 3 & -2.93 & $0.04 * *$ \\
\hline & With constant and trend & 3 & -2.90 & 0.16 \\
\hline \multirow[t]{3}{*}{ Installed capacity $(u)$} & Without constant & 1 & -2.48 & $0.01 * * *$ \\
\hline & With constant & 1 & -2.22 & 0.20 \\
\hline & With constant and trend & 1 & -1.29 & 0.87 \\
\hline
\end{tabular}

Source: Prepared by the author.

was estimated to verify the sensitivity of the results to the level of lags in the system.

The results for the neo-Kaleckian specification suggest that capacity utilization $(u)$ precedes capital accumulation in time. In other words, installed capacity 4 (whose coefficient in the equation is a measure of the accelerator) Granger-causes accumulation. The results are not sensitive to the number of lags chosen in the Granger test (for further details see table 3 and the annex).

Analysis of table 3 shows that the profits-GDP ratio does not Granger-cause capital accumulation. This result, together with the indication that capacity utilization $(u)$ Granger-causes accumulation (which ratifies the central role of the accelerator in emerging

4 In general, there is a dispute between Marxian and neo-Kaleckian economists on the use of the output-capital ratio to proxy for installed capacity in the economy. Marxians do not consider the productivity of capital (the output-capital ratio) to be an adequate measure of installed capacity (Duménil and Lévy, 1999). Capital productivity would only be the technological component of the profit rate $(r=(\pi / \mathrm{Y})(\mathrm{Y} / \mathrm{K}))$, since it measures technical change in the economy and results from the distributive conflict. Marxians explain the Brazilian economic growth miracle (1968-1973) in terms of technological change and the high level of capital productivity in the period. economies), is an indicator that income concentration and de-concentration processes would not necessarily determine the growth of the Brazilian economy in the period 1950-2008. Consequently, the economy could grow under policies of either redistribution or income concentration; but the institutional arrangement is an important explanatory component of the expansion.

In this connection, it is important to recall the ideas of Tavares and Serra (1972), who suggest that the exhaustion of the Brazilian growth model in the 1960s was caused by the weakening of investment. Those authors argue that the economy would require arrangements to secure new sources of financing to increase investment. Hence the need to re-concentrate income as a way to provide new sources of funding to increase capital accumulation. In short, Tavares and Serra (1972) believe that the paralysis or exhaustion of growth regimes are related to the system's dynamic, which creates constraints that call for new social, economic and political arrangements.

Lastly, it is seen that there is no Granger-causality relation between GDP profit share and capacity utilization. In other words, there is no time precedence between the two series.

TABLE 3

Brazil: Granger-causality relations in the economy, 1950-2008

\begin{tabular}{|c|c|c|c|}
\hline Specification & $\begin{array}{l}\text { Capacity utilization }(u) \\
\mathrm{x} \\
\text { Capital accumulation }(g)\end{array}$ & $\begin{array}{c}\text { GDP profit share }(\pi) \\
\mathrm{x} \\
\text { Capital accumulation }(g)\end{array}$ & $\begin{array}{c}\text { GDP profit share }(\pi) \\
\mathrm{x} \\
\text { Capacity utilization }(u)\end{array}$ \\
\hline \multicolumn{4}{|l|}{ Specification } \\
\hline \multirow[t]{2}{*}{$g=c+\delta \pi+\beta u$} & $\rightarrow$ & $X$ & X \\
\hline & $g$ & $g$ & $\pi$ \\
\hline
\end{tabular}

Source: Prepared by the author. 


\section{VI}

\section{Conclusions}

This article aimed to establish whether there is Granger causality between the GDP profit-share, capacity-utilization and capital-accumulation variables. The results of the Granger non-causality test for the variables in the intensive-form investment function provide an indicator of the growth regime of the Brazilian economy in the period 1950-2008.

The results of the tests show that capacity utilization on its own Granger-causes capital accumulation. It was also found that the profit share of GDP does not Grangercause accumulation. Thus the economy can have growth regimes that are either wage-led or profit-led, in certain periods. Wage-based regimes and profit-based regimes would explain the expansion processes only in the short and medium terms (Taylor, 1991).

Consequently, these results show that the growth of the Brazilian economy appears to be explained by the accelerator.

Specifically, the results show that the accelerator (the coefficient on the installed capacity variable in the regression) is the key parameter for explaining Brazilian capital accumulation. According to the neo-Kaleckian and structuralist literature, the accelerator is the main explanatory component of investment, since it has a greater effect than profits on investment in developing countries (Taylor, 1983). Other studies, such as Cuesta (1990) and Von Arnim and Rada (2011), obtained similar results using alternative methods for the study of other countries.

The results thus show that the accelerator tend to increase capital accumulation, thereby raising the level of economic activity. According to the estimations obtained, growth can be produced by either a concentration or a de-concentration of income. Periods of wage-led expansion in economies alternate with periods of profit-led expansion, as this is a short- or mediumterm phenomenon. The main factors are found to be the accelerator effect and the institutional arrangement needed to stimulate growth. As growth regimes change through time, it is advisable to proceed cautiously and intensify research to determine the current regime of the Brazilian economy.

\section{ANNEX}

TABLE A. 1

Vector autoregressive regression (VAR(3)), ordinary least squares (OLS), 1950-2008

(Dependent variable: capital accumulation $(g)$ )

\begin{tabular}{lccc}
\hline Variable & Coefficient & Standard error & $t$-statistic \\
\hline Constante & 0.039638 & 0.037287 & 1.063054 \\
$g(-1)$ & 0.954799 & 0.183519 & 5.202738 \\
$\pi(-1)$ & -0.088970 & 0.087916 & -1.011989 \\
$u(-1)$ & 0.095541 & 0.048361 & 1.975580 \\
$g(-2)$ & -0.093285 & 0.257331 & -0.362509 \\
$\pi(-2)$ & 0.095327 & 0.074971 & 1.271519 \\
$u(-2)$ & 0.008393 & 0.070331 & 0.119337 \\
$g(-3)$ & 0.105512 & 0.132798 & 0.794533 \\
$\pi(-3)$ & -0.081704 & 0.078005 & -1.047412 \\
$u(-3)$ & -0.093466 & 0.054570 & -1.712765 \\
$\mathrm{R}^{2}$ & & & 0.2099 \\
S.E. of the regression & 0.908229 & Adjusted R & 0.9055 \\
Sum of the squares of the residuals & 0.011322 & Akaike criterion & 0.3004 \\
Durbin-Watson & 0.005897 & Schwarz criterion & 0.0935 \\
\hline
\end{tabular}

Source: Prepared by the author.

Note: The regression variables are: capital accumulation $(g)$, profit share of GDP $(\pi)$ and capacity utilization $(u)$. 
TABLE A. 2

Wald test for the hypothesis that the variable profit share of GDP $(\pi)$ Granger-causes Brazilian capital accumulation $(g)$

\begin{tabular}{|c|c|c|c|}
\hline Statistical test & Value & Degrees of freedom & $p$-value \\
\hline F-statistic & 0.904804 & $(2.46)$ & 0.4117 \\
\hline$\chi^{2}$ & 1.809608 & 2 & 0.4046 \\
\hline
\end{tabular}

Source: Prepared by the author.

TABLE A.3

Wald test of the hypothesis that the capacity-utilization variable $(u)$ Granger-causes Brazilian capital accumulation $(g)$

\begin{tabular}{lccc}
\hline Statistical test & Value & Degrees of freedom & $p$-value \\
\hline F-statistic & 3.372944 & $(2.46)$ & 0.0430 \\
$\chi^{2}$ & 6.745888 & 2 & 0.0343 \\
\hline
\end{tabular}

Source: Prepared by the author.

TABLE A. 4

Vector autoregressive (VAR(4)) regression, ordinary least squares (OLC), 1950-2008

(Dependent variable: capital accumulation $(g)$ )

\begin{tabular}{|c|c|c|c|c|}
\hline Variable & Coefficient & Standard error & $t$-statistic & $p$-value \\
\hline Constant & 0.044792 & 0.035378 & 1.266118 & 0.2124 \\
\hline$g(-1)$ & 0.968530 & 0.214332 & 4.518826 & 0.0000 \\
\hline$\pi(-1)$ & -0.100200 & 0.092328 & -1.085258 & 0.2840 \\
\hline$u(-1)$ & 0.103160 & 0.047612 & 2.166659 & 0.0360 \\
\hline$g(-2)$ & -0.072161 & 0.248043 & -0.290920 & 0.7725 \\
\hline$\pi(-2)$ & 0.096273 & 0.076167 & 1.263974 & 0.2132 \\
\hline$u(-2)$ & 0.008107 & 0.074341 & 0.109053 & 0.9137 \\
\hline$g(-3)$ & 0.047919 & 0.182107 & 0.263136 & 0.7937 \\
\hline$\pi(-3)$ & 0.015815 & 0.105128 & 0.150432 & 0.8811 \\
\hline$u(-3)$ & -0.127061 & 0.098793 & -1.286133 & 0.2054 \\
\hline$g(-4)$ & 0.020818 & 0.150357 & 0.138454 & 0.8905 \\
\hline$\pi(-4)$ & -0.094231 & 0.076204 & -1.236561 & 0.2231 \\
\hline$u(-4)$ & 0.025055 & 0.068363 & 0.366495 & 0.7158 \\
\hline $\mathrm{R}^{2}$ & 0.907611 & Adjusted $\mathrm{R}^{2}$ & & 0.881214 \\
\hline S.E. of the regression & 0.011708 & Akaike criterion & & -5.854008 \\
\hline Sum of the squares of the residuals & 0.005757 & Schwarz criterion & & -5.379548 \\
\hline Durbin-Watson & 1.954304 & Prob. (F-statistic) & & 0.00000 \\
\hline
\end{tabular}

Source: Prepared by the author.

Note: The regression variables are: capital accumulation $(g)$, profit share of GDP $(\pi)$ and capacity utilization $(u)$.

TABLE A.5

Wald test of the hypothesis that the variable profit share of GDP $(\pi)$ Granger-causes Brazilian capital accumulation $(g)$

\begin{tabular}{|c|c|c|c|}
\hline Statistical test & Value & Degrees of freedom & $p$-value \\
\hline F-statistic & 1.103795 & $(2.42)$ & 0.3410 \\
\hline$\chi^{2}$ & 2.207590 & 2 & 0.3316 \\
\hline
\end{tabular}

Source: Prepared by the author. 
TABLE A.6

Wald test for the hypothesis that capacity utilization variable $(u)$ Granger-causes Brazilian capital accumulation $(g)$

\begin{tabular}{|c|c|c|c|}
\hline Statistical test & Value & Degrees of freedom & $p$-value \\
\hline F-statistic & 3.484320 & $(2.42)$ & 0.0398 \\
\hline$\chi^{2}$ & 6.968640 & 2 & 0.0307 \\
\hline
\end{tabular}

Source: Prepared by the author.

The same results were obtained for Granger causality in the VAR(4), so they are not sensitive to the number of lags in the system. Analogously, a VAR was estimated in levels to verify whether the variables Granger-cause capacity utilization and the profit share of GDP. The results showed that capital accumulation does not Granger-cause capacity utilization and the profit-GDP ratio. The full results of these tests can be obtained from the author on request.

\section{Bibliography}

Badhuri, A. and S. Marglin (1990), "Unemployment and real wage: The economic basis for contesting political ideologies", Cambridge Journal of Economics, vol. 14, No. 4, Oxford, Oxford University Press.

Bagolin, I.P., J. Gabe and E.P. Ribeiro (2003), "Crescimento e desigualdade no Rio Grande do Sul: uma revisão da Curva de Kuznets para os municípios gaúchos (1970-1991)", unpublished.

Berni, D.A., A.A. Marquetti and R. Kloeckner (2002), "A desigualdade econômica do Rio Grande do Sul: primeiras investigações sobre a Curva de Kuznets", Anais do $1^{\circ}$ Encontro de Economia Gaúcha, Porto Alegre.

Bortis, H. (1997), Institutions, Behaviour and Economic Theory: A Contribution to Classical-Keynesian Political Economy, Cambridge, Cambridge University Press.

Cuesta, J.L.L. (1990), "IS-FM macroeconomics: general equilibrium linkages of the food market in Colombia", Socially Relevant Policy Analysis: Structuralist Computable General Equilibrium Models for the Developing World, L. Taylor (ed.), Cambridge, Massachusetts, The MIT Press.

Deaton, A. (2003), "Health, inequality, and economic development", Journal of Economic Literature, vol. 41, No. 1, Nashville, Tennessee, American Economic Association.

Duménil, G. and D. Lévy (1999), "Being Keynesian in the short term and classical in the long term: The traverse to classical long-term equilibrium", The Manchester School, vol. 67, No. 6, Wiley.

Dutt, A.K. (1984), "Stagnation, income distribution and monopoly power", Cambridge Journal of Economics, vol. 8, No. 1, Oxford, Oxford University Press.

ECLAC (Economic Commission for Latin America and the Caribbean) (2012), "CEPALSTAT" [online] http://estadisticas.cepal.org/cepalstat/ WEB_CEPALSTAT/Portada.asp?idioma $=\mathrm{i}$.

Furtado, C. (1972), Análise do modelo brasileiro, Rio de Janeiro, Civilização Brasileira.

(1965), Subdesenvolvimento e estagnação na América Latina, Rio de Janeiro, Civilização Brasileira.

IBGE (Brazilian Geographical and Statistical Institute) (2011), "Tabela de recursos e usos" [online] http://www.ibge.gov.br/home/ estatistica/economia/contasnacionais/2011.

ILO (International Labour Organization) (2011), Studies on Growth with Equity. Brazil: An Innovative Income-led Strategy, Geneva, International Institute for Labour Studies.

IPEA (Institute of Applied Economic Research) (2011), "Estatísticas sociais", Ipeadata [online] http://www.ipeadata.gov.br.

Kalecki, M. (1971), Selected Essays on the Dynamics of the Capitalist Economy, Cambridge, Cambridge University Press.
Kuznets, S. (1966), Modern Economic Growth, New Haven, Yale University Press.

Marquetti, A.A. (2000), "Estimativa do estoque de riqueza tangível no Brasil, 1950-1998", Nova Economia, vol. 10, No. 2, Minas Gerais, Federal University of Minas Gerais.

Marquetti, A.A., D. Koshiama and D. Alencastro (2009), "O aumento da lucratividade expande a acumulação de capital? Uma análise de causalidade de Granger para países da ocde", Revista de Economia Contemporânea, vol. 13, No. 3, Rio de Janeiro, Institute of Economics, Federal University of Rio de Janeiro.

Marquetti, A.A. and M.C.S. Porsse (2014), "Patterns of technical progress in the Brazilian economy, 1952-2008", CEPAL Review, No. 113 (LC/G.2614-P), Santiago, Economic Commission for Latin America and the Caribbean.

Ranis, G. and F. Stewart (2000), "Strategies for success in human development", Journal of Human Development, vol. 1, No. 1, Taylor \& Francis.

Ros, J. (2000), Development and the Economics of Growth, Ann Arbor, The University of Michigan Press.

Steindl, J. (1952), Maturity and Stagnation in American Capitalism, Oxford, Basil Blackwell.

Tavares, C. and J. Serra (1972), "Além da estagnação", Da substituição de importações ao capitalismo financeiro, M.C. Tavares, Rio de Janeiro, Zahar Editores.

Taylor, L. (1991), Income Distribution, Inflation, and Growth: Lectures on Structuralist Macroeconomic Theory, Cambridge, Massachusetts, The MIT Press.

(1983), Structuralist Macroeconomics: Applicable Models for the Third World, New York, Basic Books.

Toda, H. and T. Yamamoto (1995), "Statistical inference in vector autoregressions with possibly integrated processes", Journal of Econometrics, vol. 66, No. 1-2, Amsterdam, Elsevier.

United Nations (2010), World Economic Situation and Prospects 2010, New York

Verbeek, M. (2008), A Guide to Modern Econometrics, John Wiley $\&$ Sons Ltd.

Von Arnim, R. and C. Rada (2011), "Labour productivity and energy use in a three-sector model: An application to Egypt", Development and Change, vol. 42, No. 6, Wiley.

Yamada, H. and H. Toda (1998), "Inference in possibly integrated vector autorregresive models: Some finite sample evidence", Journal of Econometrics, vol. 86, No. 1, Amsterdam, Elsevier. 